\title{
MISCELLANEOUS COMMUNICATIONS.
}

There is no Modification in the Karma Doctrine.

I have read with great interest and attention "Modifications of the Karma Doctrine," by E. Washburn Hopkins, published in the Journal of the Royal Asiatic Society for July, 1906. First of all, I must apologize to Mr. Hopkins for pointing out that his statement is not correct. Yet he has indeed studied the question from various books.

On matters like Karma, the authorities must be taken only from Dharma Sastras, Gita, and Vedantic literature, but not from the Bharata, the Puranas, and books of such a class. In Bharata every person, when he or she speaks or replies, quotes some sentence of morality. Many of such moral sayings are real ones, but are not suited to the occasion. As that book contains so many moral sayings and nearly all the legends of the past, it is called the "Fifth Veda." I shall, however, try to deal with all the quotations in the order in which Mr. Hopkins bas put them in his essay. But I shall leave out the small quotations here and there dwelt upon, consisting of a word or two.

I. "As a man himself sows, so he himself reaps; no man inherits the good or evil act of another man" (Mbh.). The first portion is clear enough, but Mr. Hopkins has taken a somewhat wrong meaning of the second part and based his argument on it throughout his essay. The real meaning of the latter part of it is that no man inherits the good or evil act of another man (done in his previous existence, but not in the present life). 
If a man causes good or evil to another in this life, the giver reaps that action in the next or future existence. Suppose a person helps the poor; that person reaps the fruit of that action in his future life; but the receiver does not get that help by his own action in his previous life. In the same way, if a person causes hurt to a man, that person may be punished by the king, or reap the action in his future existence. The sufferer may get some compensation from the person who does harm to him either, in some cases, through the king or in his future existence.

II. "Whether with eye or thought or voice or deed, whatever kind of act one performs, one receives that kind of act in return" (Mbb.). I hope Mr. Hopkins will allow me to use the word ' mind ' for 'thought.' Generally, mind, word, and deed are taken into consideration in the Dharma Sastras, but not the eye. If the eye is tuken into consideration all the other organs should likewise be taken. Therefore the action of the eye should be omitted. Here the dialogue is between Yudhishthira and old Bhishma. The latter was on his deathbed and answers the former's questions on various subjects. As it was a dialogue, several questions were re-asked, generally in a different way, and so the old man answers them differently according to the circumstances of the conversation and his remembrance. This dialogue continued not for a short time, but for several days. This fact must be, first of all, kept in mind. However, the meaning of the above quotation is that if a man's mind or word or deed is pure or impure in this life, it will have similar character in his future life. The moral to be drawn from the above passsage is : Every act is first produced in the mind, and would end either in word or in deed or in both. Therefore one must try to be pure in mind, word, and deed in this life; then in his future form no impurity would be in mind, and consequently no evil word or deed would be spoken or done.

III. "The deed does not die." This means by itself that the result of the deed must be reaped or be destroyed or mitigated by sacrifice, penance, and repentance; or it must 
be entirely destroyed by the knowledge of God. From the Hindu point of view I do not deny the effect of the curse and the power of sorcery. But when these matters are dealt with in the Puranas, they are simply the subject-matter of the replies given to questions asked. The Puranas are laden with stories whose slightest reality was never in existence. They were created to teach morality, or to praise a person, or to answer questions asked, or to describe unknown events and arts, or to mitigate the then existing misbeliefs. Therefore when a man takes the great subjects like that of Karma, he should not go to the Puranas for supporting or for contradicting a statement on the subject.

Again, Mr. Hopkins mixes up God and Vidhi as if they were one, as many Hindus do even up to date. Divam means God and Vidhi means Fate. But Divam is wrongly used for Fate in the Puranas. There we must only take the word Divam for the word Fate. Fate means what one has done in previous existences and has fallen to reap in this life only. Many Hindu philosophers think that one's Fate could not be destroyed or mitigated by the knowledge of God. I don't agree with them, but believe that it will, as a few of them have decided, be destroyed by the knowledge of God. Knowledge of God is not a mere belief in the existence of God, but it is the knowledge by which alone the soul gets the everlasting abode Moksham.

Now I must turn to the Karma doctrine again. As contrary to the first rule, viz. "No man inherits the good or evil act of another man," the author quotes some words which show that the husband shares the fruit of the acts of his wife with her, and vice versa, and that the king shares the good and evil actions of his subjects.

Among Hindus there are many ceremonies and actions that have to be performed by the husband and wife jointly, but not separately. Even among Christians there are certain oaths to be taken between the husband and wife at the marriage ceremony. It is an admitted belief that if either of these two fails to fulfil them, the party would suffer for it. If they both act up to it, they would enjoy happiness. The 
Hindu belief in this matter is also based on the above theory. As they believe in the transmigration of the soul, they have taken the effect into the future life.

If the king rules his people with ability and sees they do no hurt to one another, he would reap a share in the fruit of their actions. If, on the other hand, his subjects do mischief to one another by themselves, the king takes a share in that evil. But we must not account for every action the king or his people may perform.

IV. Is a voluntary transfer of good Karma recognized? Yes, it will go to another when transferred. For the sick man we pray for his recovery. For the dead we pray that his sins may be forgiven. The Hindus go a little bit further in this point. They believe that Danams (giving away money) to Brahmins would relieve the suffering of the giver. If a man gives another some money out of his savings, the receiver enjoys the fruit of that sum. There are several legends in the Puranas dealing with the transfer of good Karma. But here one should note that one could transfer one's good Karma of this life but not that of the previous lives. That Karma is stored for him; he alone can destroy or mitigate it by his good deeds.

V. Is Karma inherited into the family? Yes, it is inherited, but not every kind of Karma that one performs. It is more or less similar to the case of the husband and wife, and that of the king and his subjects. If a man acquires a fortune righteously, his children enjoy it in succession. If, on the other hand, the fortune is acquired fraudulently, his children suffer for it in many ways. If any good act is done for the benefit of the family, it would be reaped by the children. Mr. Hopkins here quotes : "Loose from us paternal sins, and loose what we in person have committed." Unless one tries to destroy his paternal sin by his good acts, that sin will never leave the family without reaping. Suppose a man has inherited a curable disease from his parents, he would get free from it by medicine and exercise. For the former, viz. treatment, he spends a part of his fortune, or for the latter he goes under some bodily 
trouble. In the case of incurable diseases he mitigates them by the above means.

VI. "Neither the son by the Karma of his father, nor the father by the Karma of his son, go, bound by good and evil deeds, upon another course.". This quotation needs not much explanation. It is the general rule contrary to the above special rule. Hindu teaching first gives general rules and then finishes with special rules, and in some cases with extraordinary rules. There one must think well over the circumstances of each case. Here the author gives the story of Yayati as contradictory to the above rule. This story is not a real one, but one given for teaching a moral.

Then Mr. Hopkins gives two more quotations to establish that the parents' Sila and Bhava are inherited by the son. Here Sila or Bhava has nothing to do with Karma.

In conclusion he gives a quotation to show that the fruit of an act will appear at the corresponding period of life in the next birth. This is again what old Bhishma said to Yudhishthira. This is an old saying, but not an authority to be taken. Even now very old women even in rural villages utter this very same often. I think I have touched on all the principal quotations and authorities given in Mr. Hopkins' contribution. Karma is divided into three classes, viz., (1) Agami or Vartamana, (2) Sanchita, (3) Prarabdha. All we do in this life and reap in this and future lives is called Agami or Vartamana Karma. All the Karma that could not be reaped in one existence and that is, therefore, left back without being reaped in the. previous lives is called Sanchita Karma. All that Karma. whose results we reap but could not avoid by our own. exertions in this life is called Prarabdha Karma.

V. S. R., Maharajah of Bolhiti.

\section{ArChæology in South India.}

A period of exactly twenty years has elapsed since, at Christmas, 1886, I made an expedition to the north of the 